\title{
Effects of plasma immersion ion implantation on fatigue properties of titanium alloy surfaces
}

\section{Efeitos da implantação iônica por imersão em plasma sobre propriedades de fadiga na superfície de liga de titânio}

Maria Luiza Rinaldi de Souza ${ }^{1,2}$, Bruno Bacci Fernandes ${ }^{1,2,3}$, Stephan Mändl ${ }^{3}$, Rogério Moraes Oliveira ${ }^{1}$, Mario Ueda ${ }^{1}$, Alfeu Saraiva Ramos ${ }^{4}$

\begin{abstract}
This paper reports on nanocharacterization of commercial Ti-6Al-4V and sintered Ti-Si-B alloys after surface treatment by high temperature plasma immersion ion implantation (HTPIII) to investigate fatigue in addition to hardness and wear properties. The results show that HTPIII is an effective method for improvement of the mechanical and tribological properties of the conventional Ti-6Al-4V alloy, however higher temperatures are necessary to produce the same gain on sintered Ti-Si-B alloys. For the Ti-6Al-4V sample after HTPIII the SIMS experiments identify a nitrogen-rich layer with a thickness of about $1 \mu \mathrm{m}$. The untreated samples show a barely visible nitrogen signal below the surface oxide, indicating a large nitrogen uptake and retention during the HTPIII process. Both HTPIII treated alloys presented higher hardness and wear resistance, but - surprisingly - lower fatigue resistance.
\end{abstract}

Keywords: Titanium alloys; High-energy ball milling; Plasma immersion ion implantation; Tribological properties.

\section{RESUMO}

Este artigo informa sobre a nano-caracterização de ligas de Ti-6Al$4 \mathrm{~V}$ comerciais e ligas de Ti-Si-B sinterizadas após o tratamento de superfície por implantação iônica por imersão em plasma de alta temperatura (3IPAT) para investigar a fadiga, além da dureza e propriedades de desgaste. Os resultados mostram que a 3IPAT é um método eficaz para melhoria mecânica e tribológica das propriedades da liga de Ti-6Al-4V comercial, porém maiores temperaturas são necessárias para produzir o mesmo ganho em ligas de Ti-Si-B sinterizadas. Para a amostra Ti-6Al-4V após a 3IPAT, os experimentos de SIMS identificam uma camada rica de nitrogênio com uma espessura de cerca de $1 \mu \mathrm{m}$. As amostras não tratadas mostram um sinal de nitrogênio pouco visível abaixo do óxido da superfície, indicando uma grande captação e retenção de nitrogênio durante o processo de 3IPAT. Ambas as ligas tratadas com 3IPAT apresentaram maior dureza e resistência ao desgaste, mas - surpreendentemente menor resistência à fadiga.

Palavras-chave: Ligas de titânio; Moagem de bolas de alta energia; Implantação iônica por imersão em plasma; Propriedades tribológicas.

\footnotetext{
IInstituto Nacional de Pesquisas Espaciais - Laboratório Associado de Plasmas - São José dos Campos (SP) - Brazil

${ }^{2}$ Universidade Braz Cubas - Mogi das Cruzes (SP) - Brazil

${ }^{3}$ Leibniz Institut für Oberflächenmodifizierung - Leipzig - Germany

${ }^{4}$ Universidade Federal de Alfenas - Poços de Caldas (MG) - Brazil

Correspondence author: Maria Luiza Rinaldi de Souza - Instituto Nacional de Pesquisas Espaciais, LAP/INPE, Av. dos Astronautas 1758, Caixa Postal 515, São

José dos Campos (SP) - Brazil

E-mail: mlrinaldis@hotmail.com

Received: 13/07/2017 Approved: 22/11/2017
} 


\section{INTRODUCTION}

Lightweight materials capable to withstand high temperatures with friction and/or oxidation are a demand imposed by several transportation and power generation systems, as in high speed aircrafts and engines, respectively. In order to comply with such requirements, the improvement of surface properties of these materials is essential, as well as the understanding of the links among their composition, processing method, microstructure and properties ${ }^{(1)}$. In addition, high temperature resistant alloys must combine two major requirements when thermal cycles are applied: low scale growth rate and adequate scale adherence ${ }^{(2)}$.

Materials such as stainless steels, refractory metals and alloys, and superalloys are especially creep-resilient and commonly employed in high temperature service applications ${ }^{(3)}$. Nevertheless, modern surface functionalization is often applied. Ion implantation and its variants are still rarely commercially used for metal alloys - while they are state-of-the-art and indispensable for semiconductor applications. Especially the poor tribological properties of titanium alloys had hampered the increase of their technological applications ${ }^{(4-6)}$, while PIII has been very effective in improving their tribological properties $^{(7-9)}$, and consequently in increasing their lifetime.

Titanium alloys are classified according to the concentration of alloying elements added to modify their microstructure and mechanical properties. Titanium exists in two crystallographic forms. At room temperature, unbound titanium (commercially pure) has a compact hexagonal crystal structure and crystal structure called alpha phase ( $\alpha$ ). At $883^{\circ} \mathrm{C}$ occurs the transition from compact hexagonal to body-centered cubic structure, known as beta phase $(\beta)$. The microstructure of annealed unbound titanium is acicular alpha, the presence of this microstructure indicates that the material was heated to above beta temperature ${ }^{(10)}$. Commercial Ti-6Al-4V is best known for having compact hexagonal crystal structure (alpha phase) and body-centered cubic (beta) present in its microstructure at room temperature, combining strength and corrosion resistance and formability with machinability ${ }^{(11)}$.

The titanium alloys are very advantageous because have good mechanical tensile strength (900 to $1200 \mathrm{MPa}$ ), good corrosion resistance, good fatigue strength, low thermal conductivity, low density and high E/m ratio (modulus of elasticity/mass). Such alloys the design of lightweight and sturdy structures that are capable of working in a temperature range -150 to $600{ }^{\circ} \mathrm{C}$. However, as already mentioned above, these alloys also have some disadvantages, as their poor tribological properties, with high coefficients of friction, high rates of wear and low lubrication during their movements and contacts with solid surfaces $^{(12)}$.

PIII is especially promising because it allows the transference of laboratory processes to industrial applications. Threedimensional characteristic is one of the reason for such possibility, i.e. the entire surface of parts with complex shapes can be treated without changing their masses ${ }^{(13,14)}$. Independent temperature control is another advantage, since simultaneous heating of the substrate is crucial for the treatment of $\mathrm{Ti}$ alloys to promote diffusion of the implanted ions ${ }^{(15)}$. For instance, the Ti-6Al-4V alloy treated at $800-900{ }^{\circ} \mathrm{C}$ by PIII had implanted nitrogen depths above $1 \mu \mathrm{m}^{(16,17)}$, while only a few hundred nanometers is obtained using conventional PIII. The most significant improvements on the Ti-6Al-4V surface obtained by HTPIII led to an implanted layer with thicknesses up to $20 \mu \mathrm{m}$, in which the substrate was heated up to $800{ }^{\circ} \mathrm{C}$ with the help of electron bombardment ${ }^{(18-20)}$. Concerning Ti-Si-B alloys, various properties and production pathways have been studied to increase the final working temperatures for titanium alloys ${ }^{(21-27)}$. The adopted compositions were used to produce alloys with intermetallic phases, since the research of such titanium alloys is rare and the study of the effect of these phases is important for the discovery of new advanced materials. Then, high boron and silicon contents were employed in the initial preparation of powders that were processed by high energy ball milling. Boron proved to be a promising material for increasing the oxidation resistance of the material. Formation of silica layer on material surfaces is well-known as a beneficial for increasing the oxidation resistance, mainly because the oxygen diffusion is smaller through such crystalline layer than in any glassy film. Boron-based film contributed to crystallization of the formed surface, and consequently have shown to be interesting for the reduction of the oxidation rates of silicon carbide based materials.

While high hardness and wear resistance are commonly desired attributed, more complex considerations have to be taken into account for complicated environments: too brittle surfaces are supposedly to be avoided to prevent catastrophic failure with subsequently increased third-body abrasive wear while too ductile surfaces are prone to excessive, prolonged wear. An even more intricate problem is the long-term fatigue behavior under sustained loading conditions below the yield strength under single, instantaneous loading conditions. As conventional experimental testing and subsequent analysis designed for fatigue experiments of bulk materials are not applicable as (i) the maximum load should be within the modified surface layer and (ii) the typical lengthscale is less than $100 \mathrm{~nm}^{(28-31)}$.

Thus, novel approaches and developments of alternative techniques have been used. Investigation of indentation fatigue behavior, for example, is crucial to build a relationship between nanoscale tests and conventional fatigue testing ${ }^{(30-34)}$. In this work, nanoindentation tests were employed to study the mechanical fatigue properties of titanium alloys (sintered Ti-Si-B and commercial Ti-6Al-4V) surface modified by HTPIII. The results after the plasma treatment are correlated with reciprocating wear tests and elemental depth profiles obtained by secondary ion mass spectroscopy (SIMS). 


\section{EXPERIMENTAL PROCEDURES}

High-purity elemental powders - Ti (99.9 wt.\%, spherical, $<150$ mesh), $\mathrm{Si}$ (99.999wt.\%, irregular, <325 mesh) and B(99.5 wt.\%, angular, < 325 mesh) - were used in this work to prepare four different powder mixtures: Ti-5.5Si-20.5B, Ti-7.5Si-22.5B, Ti-16Si-4B and Ti-18Si-6B (at.\%). The milling process was carried out at room temperature in a Fritsch planetary ball mill under an argon atmosphere using rotary speed of 240-300 rpm, a ball-to-powder weight ratio of 10:1 and stainless steel vials $(225 \mathrm{ml})$ and balls. The mechanically alloyed powders were uniaxially pressed for 2 minutes at $110 \mathrm{MPa}$ and then isostatically pressed for 1 minute at $300 \mathrm{MPa}$, both operations being performed at room temperature. Subsequently, these green compacts were hot-pressed with $30 \mathrm{MPa}$ and $1100{ }^{\circ} \mathrm{C}$ for 20 minutes into a graphite die under argon atmosphere. Some additional reference samples were produced without cold pressing.

Before HTPIII treatment, the samples were grounded on $\mathrm{SiC}$ papers and polished with colloidal silica suspension. Additional Ti-6Al-4V sample discs of 15-mm diameter and 3-mm thickness were also grounded, polished and cleaned in ultrasound acetone bath. The experimental set-up for the nitrogen HTPIII, where the heating of the substrate is performed with the help of electron bombardment, has been previously described ${ }^{(35)}$.

For the present experiments, each titanium alloy sample was connected to a tungsten wire that in turn was fixed on a stainless steel rod playing the role of the discharge anode. This assembly was positively polarized to $+700 \mathrm{VDC}$ in relation to the grounded chamber wall and simultaneously by negative $\mathrm{HV}$ pulses of $-7 \mathrm{kV}$ (length of $30 \mu \mathrm{s}$ and repetition rate of $400 \mathrm{~Hz}$ ). This process was operated in vacuum environment in nitrogen atmosphere at a working pressure of $10^{-3}$ Torr for $60 \mathrm{~min}$. A thermionic oxide cathode generates primary electrons to ignite the glow discharge and to heat the substrate up to $800^{\circ} \mathrm{C}$. The implantation of nitrogen ions takes place when the high negative voltage pulses are applied.

The nitrogen depth profiles implanted into $\mathrm{Ti}$ alloys were measured using time-of-flight secondary ion mass spectrometry (ToF-SIMS). The thickness of the nitrogen containing regions was estimated from the sputtering time by measuring the depth of the craters and assuming a linear sputter rate within the craters. Tribological evaluations of the sample surfaces were conducted with a CSM tribometer with measurements of the dry friction coefficient accomplished in an oscillating ball-on-disk tribometer. The following parameters were used: load of $1 \mathrm{~N}$ with a 4.76- $\mathrm{mm}$ diameter alumina ball as a counterpart material, maximum speed of $10 \mathrm{~cm} / \mathrm{s}$ and total track length of $2 \mathrm{~mm}$. The afflicted surfaces after the wear test were examined using a scanning electron microscope employing the secondary electron detector mode to find out more information about the wear mechanisms. Roughness and surface profiles after wear test were measured with an optical profilometer.

Additionally, dynamic nanoindentation was employed for surface characterization with conventional nanohardness being measured using a quasi-continuous stiffness measurement (QCSM). In this configuration, the increase of the load is stopped for a period of time of $3 \mathrm{~s}$ where the voltage for the piezoelectric element is overlaid with a sinusoidal oscillation. The employed indenter was a Berkovich three-sided pyramidal diamond. An average of 10 single measurements was used to determine the average hardness. Furthermore, the nanofatigue tests were conducted in the same nanoindentation equipment, however now with a spherical diamond indenter (tip radius of $10 \mu \mathrm{m}$ ). The samples were subjected to cyclic contact tests by repeatedly indenting the same area at maximum loads of $100-750 \mathrm{mN}$ with minimum loads of 1.0-7.5 mN, respectively. Because of software limitations, only a maximum of 300 cycles are allowed without the indenter leaves the surface. Nevertheless, a larger number of cycles were performed at the same position by repeating this 300-cycle experiment several times. Using the same spherical indenter, nanowear experiments were performed with loads of 10 , 50 and $100 \mathrm{mN}$ to make tracks with $80-\mu \mathrm{m}$ length.

\section{RESULTS AND DISCUSSION}

For the Ti-6Al-4V sample after HTPIII the SIMS experiments identify a nitrogen-rich layer with a thickness of about $1 \mu \mathrm{m}$ (Fig. 1). The untreated samples show a barely visible nitrogen signal below the surface oxide, indicating a large nitrogen uptake and retention during the HTPIII process. The absolute nitrogen content after ion implantation is estimated to be around $30-50$ at. $\%$ using results from comparable samples ${ }^{(36)}$. The

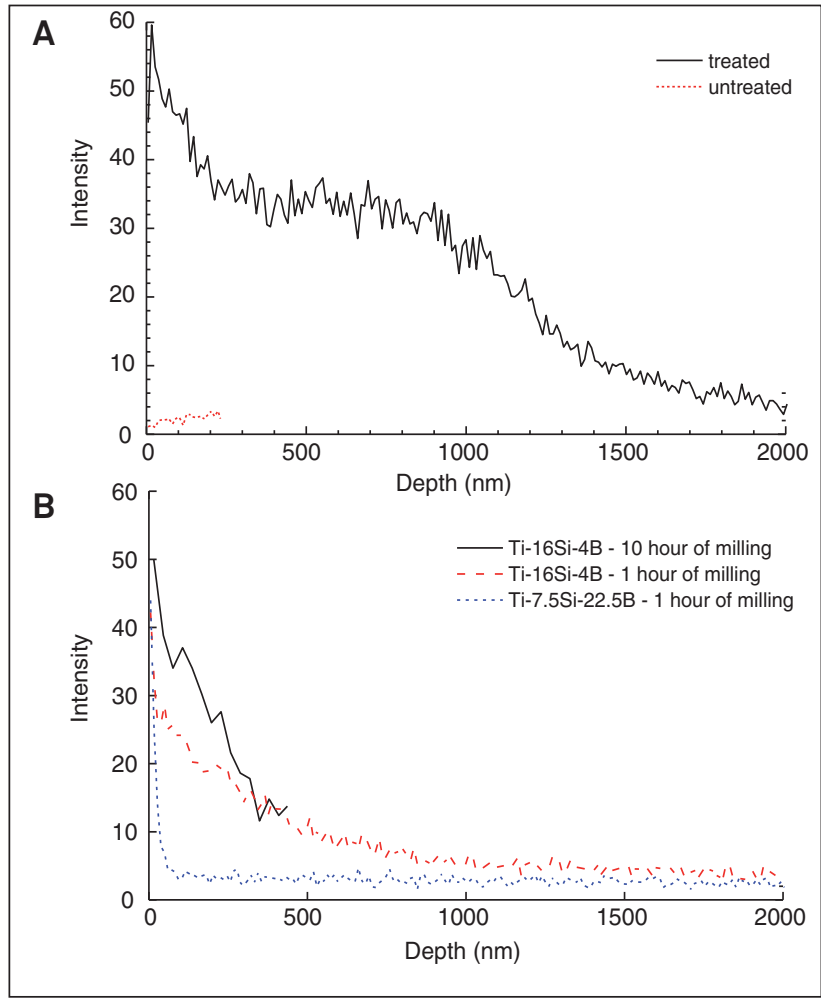

Figure 1: SIMS profiles of the: (A) Ti-6Al-4V and (B) Ti-Si-B alloys. 
immediate surface region with the enhanced nitrogen ion intensity could be an artifact due to matrix effect induced by a surface oxide. In addition to the nitride containing layer, a deep diffusion tail with nitrogen in solid solution can be observed. The diffusion rate is in agreement with published data. In contrast, much lower retained nitrogen was observed for the Ti-Si-B sintered alloys under identical implantation conditions. Both the different compositions and duration of ball milling have influenced such implantation and the nitrogen plateau observed in the commercial alloy does not appear in the sintered alloys. The more intense milling conditions produce smaller grain size, which consequently generate predominant diffusion along grain boundaries and a strongly reduced uptake of nitrogen within the bulk by the grains. Furthermore, a competition between boron and nitrogen for bonding with titanium atoms may explain the lower nitrogen uptake for higher boron content. However, the resulting microstructure should be dissimilar to quaternary Ti-Si-B-N nanocomposites produced by PECVD techniques, where a crystalline phase is embedded in an amorphous matrix ${ }^{(37)}$. Nevertheless, the microstructure should be investigated in further experiments.

As a result of the nitrogen implantation, changes in the tribological properties should be expected. Wear in a reciprocating ball-on-disc geometry show an improvement for both classes of materials (Ti-6Al-4V and sintered Ti-Si-B), which is more pronounced for the Ti-6Al-4V alloy than for the Ti-Si-B sintered materials. The wear mechanisms of the untreated commercial alloy have been identified as a mixture between abrasive and adhesive while in the HTPIII treated alloy, only abrasive wear is observed (Figs. 2a and 2b). Recently published work indicates that a transition towards strain-induced brittle fracture is occurring, albeit at a lower, absolute level as the surface hardness is increased after nitriding ${ }^{(38)}$. For the Ti-16Si-4B sintered alloy, localized adhesive and abrasive wear can be viewed in SEM images after nitrogen implantation and wear testing (Fig. 2c). The roughness (Ra) is always increased after nitrogen implantation: for the commercial Ti alloy from $40 \mathrm{~nm}$ to up to $220 \mathrm{~nm}$, as verified by optical profilometry. The sintered Ti-16Si-4B alloys present higher roughness in untreated condition (around $110 \mathrm{~nm}$ ) and the HTPIII further increases this value to around $160 \mathrm{~nm}$.

Reducing the length scale of the experiments, nanowear experiments with a diamond tip also confirm that the HTPIII treatment significantly increased the wear resistance of the Ti-6Al-4V surface (Fig. 3). For lower loads of $10 \mathrm{mN}$, the wear track cannot be identified, respective visualized by SEM in the treated surface as the material removal is too small, whereas in the untreated sample a clear track is observed with this low load, even without clear removal of material. Similar, this lower load did not leave any impression detectable by SEM in the Ti-16Si-B alloy (either treated or not). Thus, a combination of resistance to plastic deformation (i.e. higher hardness) and resilience (increased wear resistance) can be inferred for both HTPIII
A

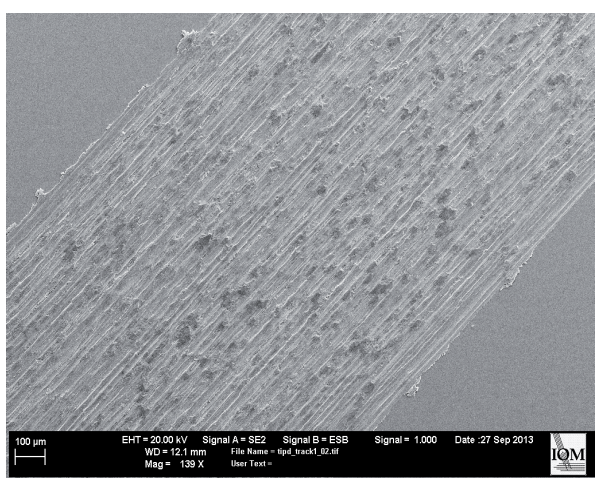

B

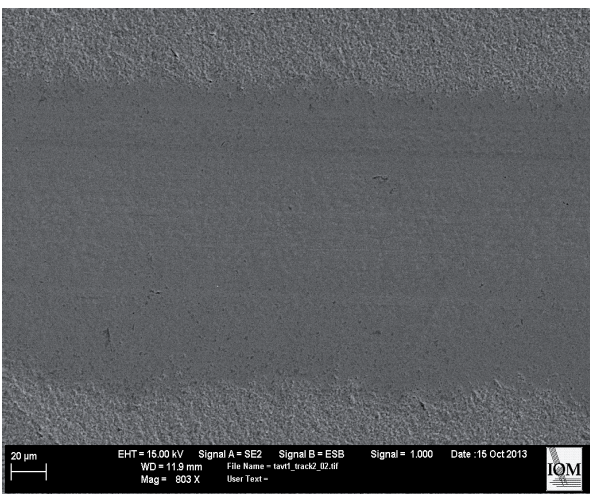

C

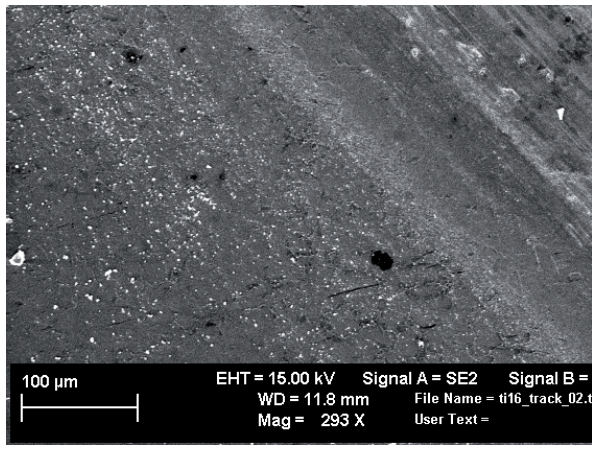

Figure 2: SEM images of tracks after ball-on-disk test of the (A) untreated Ti-6Al-4V alloy, (B) treated Ti-6Al-4V alloy by HTPIII and $(C)$ untreated Ti-16Si-4B alloy.

treatments and Ti-Si-B alloys. Flaking and cracking typical for scratch test on coated surfaces are observed neither, indicating a very strong bonding of the nitrogen containing layer on the original material, as expected from the ion implantation and inward diffusion process.

The absence of plastic deformation during nanowear experiments is confirmed by dynamic nanohardness test. Here, the nitrogen implantation increased the hardness of the Ti-6Al-4V alloy three times, which is evidence of the presence of a titanium nitride phase in this surface region. However, the Ti-Si-B alloys had almost no increase of such property, as the original hardness is already similar to the hardness of the nitrided Ti-6Al-4V alloy (Fig. 4). This shows that in the Ti-Si-B alloys the treatment does not have the same effect because its phases of high hardness and oxidation resistance do not allow the absorption of the nitrogen so easily. 
Nanoindentation has been developed to enable mechanical measurements of thin films even on complex surfaces. This technique examines the loads and displacements of a pressured tip against the surface of the materials of interest. By correlating experimental and computational results, nanoindentation becomes a fast and non-destructive procedure as long as the stress-strain response of a given thin film is determined. In nanoindentation of solid materials, the formation of circular cracks is favored by positive radial stresses which are reduced by discharging. The radial stresses become more compressive in the discharge, however, they are initially higher than the circumferential stresses producing conditions for the nucleation and initial growth of circular cracks ${ }^{(39)}$. Regarding Nano fatigue experiments, at loads above $100 \mathrm{mN}$, the first cycle of all indentations generates open load-depth curves with a significant plastic contribution, but the second and subsequent cycles are closed, indicating pure elastic deformation, and almost identical. Such a behavior indicates work hardening created by the first loading as reported in the literature ${ }^{(40)}$. A higher plastic contribution was observed on the first cycles applied in the untreated samples. No cracks or deformation effects at the surrounding are observed in fatigue experiments with loads lower than $200 \mathrm{mN}$ and 15,000 cycles in untreated Ti-6Al-4V surface. As shown in Fig. 5a, more cycles are necessary to allow the observation of spallation with such low load levels. However, the nitrogen containing, treated surface presents cracks already at loads of $300 \mathrm{mN}$ and 300 cycles. The embrittlement of the surface region due to the nitrogen induced phase transformation could be the origin of this behavior ${ }^{(41)}$.

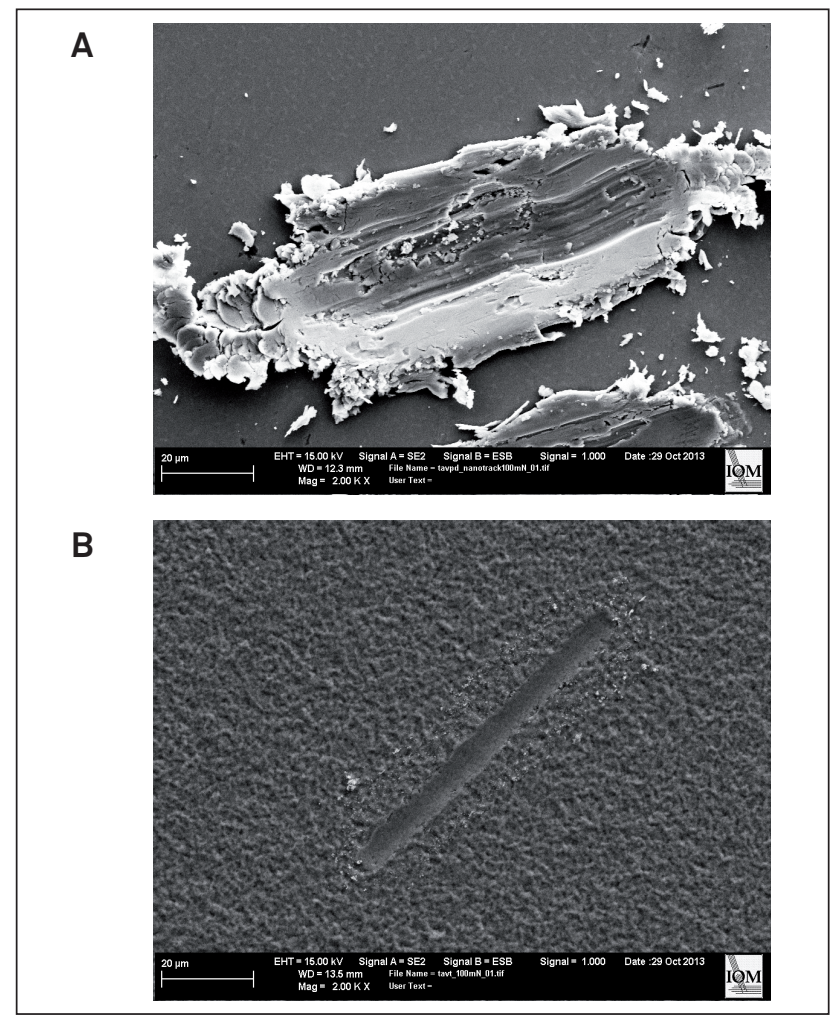

Figure 3: Wear tracks using $100 \mathrm{mN}$ of load on the surface of the Ti-6Al-4V alloy: $(A)$ untreated and $(B)$ treated.

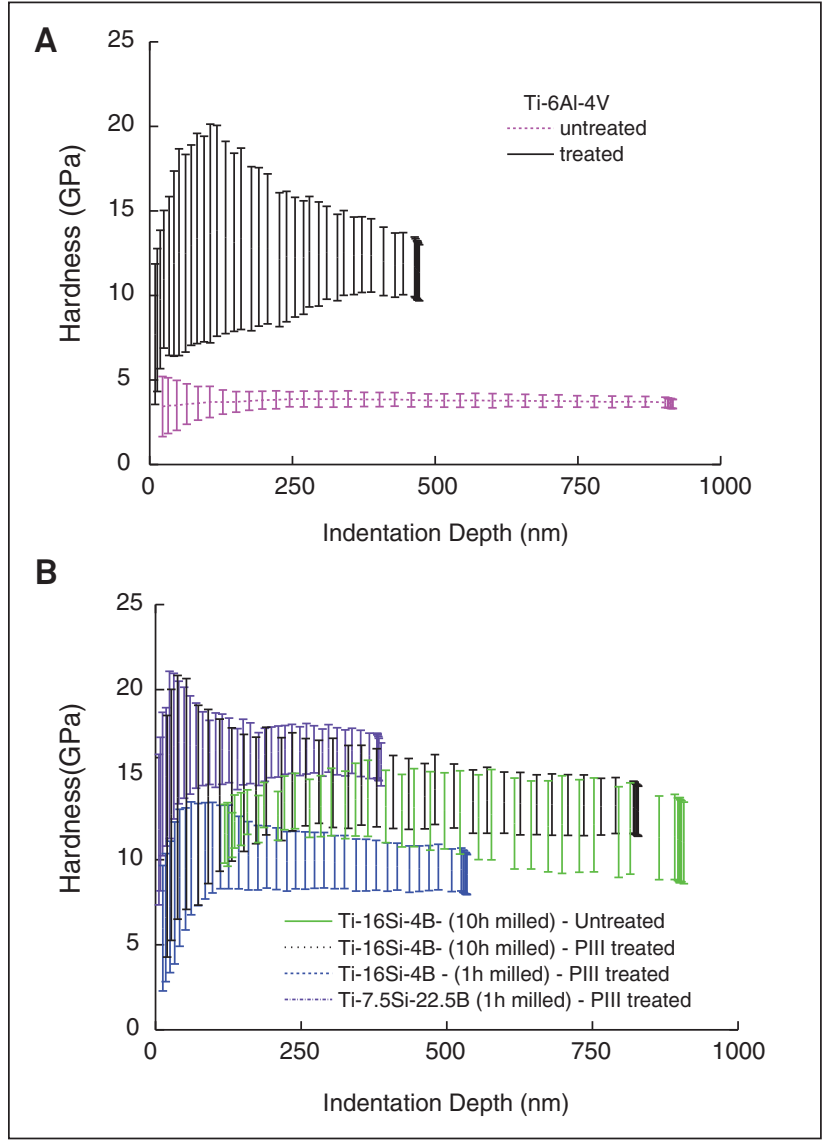

Figure 4: Hardness profiles of titanium alloys: (A) Ti-6Al-4V, (B) Ti-Si-B.

A

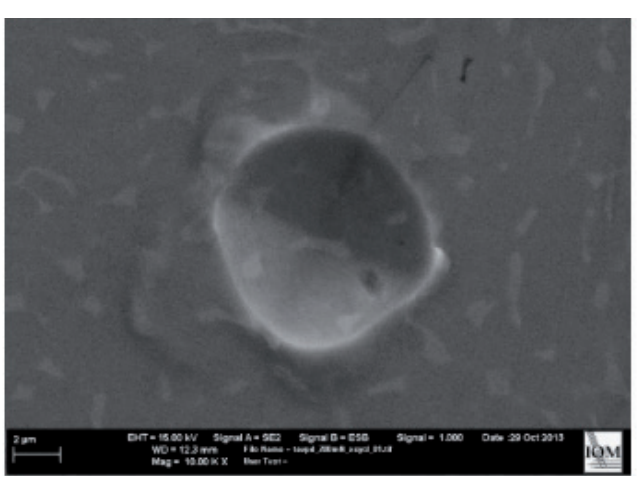

B

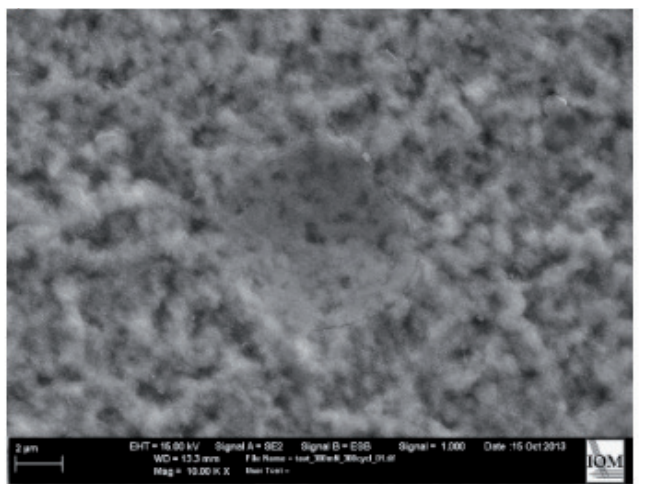

Figure 5: Fatigue indentations of the Ti-6AI-4V alloy: (A) untreated $(88,000$ cycles of $200 \mathrm{mN})$ and $(B)$ treated $(300$ cycles of $300 \mathrm{mN})$. 
For untreated and treated Ti-16Si-4B surfaces, radial cracks are observed in fatigue experiments with loads of $200 \mathrm{mN}$ and 3,000 cycles (Fig. 6). Axial cracks can be also detected at regions where loads of $750 \mathrm{mN}$ were applied in these samples. The depth differences of the first 300 cycles (Fig. 7) between untreated and treated Ti-Si-B alloys are much lower (around 5\%) than the difference for the commercial titanium alloy (around 50\% after nitrogen insertion). Of course, this behavior is directly correlated with the relative changes in hardness after nitrogen insertion. While a direct calculation of the stress distribution is possible for spherical indenters ${ }^{(42)}$, a clear definition of the onset of fatigue on a nanoscopic scale is much more difficult, if not impossible, whereas the macroscopic failure - in contrast - for conventional bulk material is much more easily to observe and analyze ${ }^{(43)}$. Here, the direct observation of the onset of fatigue would require detecting a crack within a volume or surface area close to zero or as small as the initial contact area as the stress distribution is highly inhomogeneous. Hence, the experimental resolution in SEM will always lead to an artificial over reporting of the fatigue limit in this kind of Nano fatigue experiments. Nevertheless, an improved fatigue response for sintered Ti-Si-B alloys after HTPIII seems to be possible when the presented exploratory work is expanded to include different temperatures and lower fluences. The concentration on easily measured hardness and wear data may not represent actual industrial use as the loading conditions will be very different.

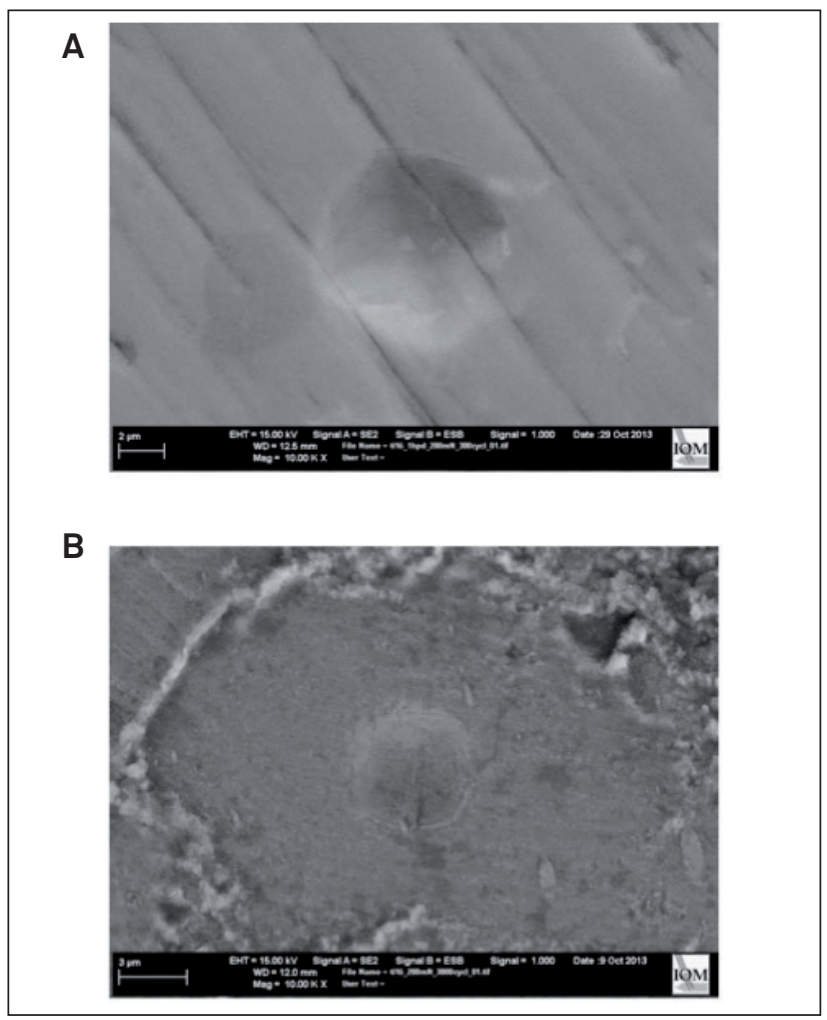

Figure 6: Fatigue indentations of the Ti-16Si-4B alloy: (A) untreated-300 cycles and (B) treated-3,000 cycles.
Nanofatigue can be one possibility for a more realistic - while also more complex - description of the surface properties.

The implantation success of the Ti-6Al-4V alloy can be also observed in the depth data, when this untreated one present a large difference between initial plastic deformation and the subsequent elastic cycles (Fig. 7). This feature is completely missing for treated samples that have a small difference between these deformation types, again indicative of the higher hardness, respective resistance to plastic deformation. Another clear difference between the commercial alloys and the Ti-Si-B alloys is the presence of a treated surface with low hardening rate, as evidenced by the reversal in the graph of the former alloy. These measurements need further studies to reduce the doubts from equipment errors and structural heterogeneity of these alloys.

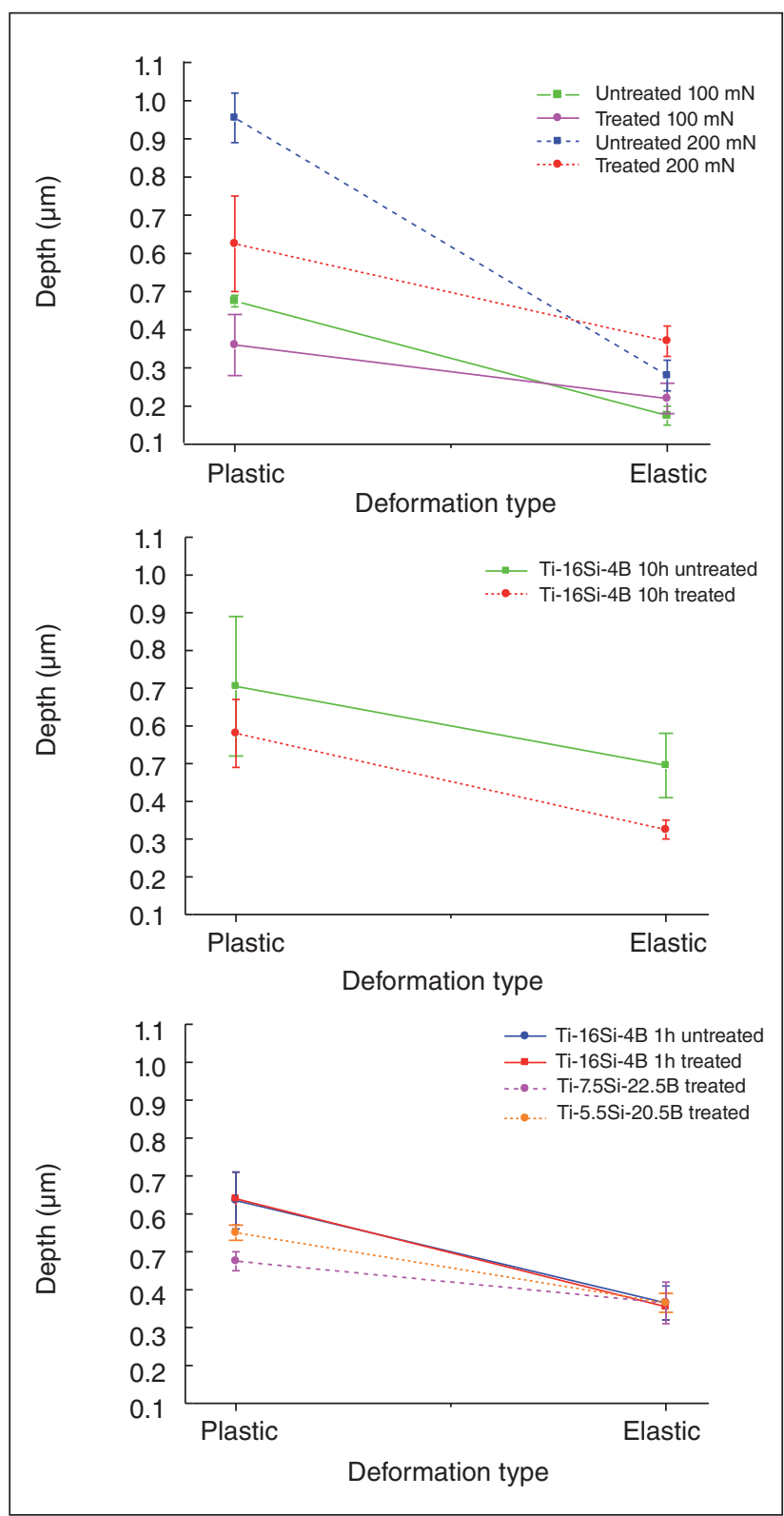

Figure 7: Analysis of fatigue depths $(200 \mathrm{mN})$. 


\section{CONCLUSIONS}

The process of implantation of high temperature nitrogen plasma immersion generates a nitrogen-rich surface layer that reduces the coefficient of friction and wear rate of a conventional Ti-6Al-4V alloy. This treatment also increases hardness while decreasing fatigue resistance due to surface embrittlement. Nitrogen implantation increased the hardness of the Ti-6Al-4V alloy three times, evidencing the presence of a titanium nitride phase in this surface region. However, the Ti-Si-B alloys had almost no increase of such property, since the original hardness is already similar to the hardness of the nitrided Ti-6Al-4V alloy. This shows that in the Ti-Si-B alloys the treatment does not have the same effect because its phases of high hardness and resistance to oxidation do not allow the absorption of nitrogen as easily. These new alloys already have high hardness and wear resistance, but also present low resistance to fatigue, even without addition of nitrogen to the surface. The results indicated that both HTPIII treated alloys showed improvements, although in different proportions.

\section{ACKNOWLEDGMENTS}

We appreciate the financial support from the CNPq, MCT and FAPESP (grants \# 2011/00872-2 and \# 2012/21009-3, São Paulo Research Foundation).

\section{REFERENCES}

1. WILLIAMS, J.C.; STARKE JR., E.A., Acta Mater. 51 (2003) 57755799.

2. RIFFARD, F.; BUSCAIL, H.; CAUDRON, E.; CUEFF, R.; ISSARTEL, C.; PERRIER, S., Appl. Surf. Sci. 252 (2006) 3697-3706.

3. CALLISTER JR.,W.D., Materials Science and Engineering: An Introduction, John Wiley \& Sons, Inc., New York, NY, 2007, p. 243.

4. KHALED, M.M.; YILBAS, B.S.; AL-QARADAWI, I.Y.; COLEMAN, P.G.; ABDULMALIK, D.; SEDDIGI, Z.S.; ABULKIBASH, A.; ABUSHARKH, B.F.; EMAD, M.M.. Surf. Coat. Technol. 201 (2006) 932937.

5. YU, C.; ZHU, S.; WEI, D.; WANG,F., Surf. Coat. Technol. 201 (2007) 7530-7537.

6. CREMASCO, A.; OSÓRIO, W.R.; FREIRE, C.M.A.; GARCIA, A.; CARAM, R., Electrochim. Acta 53 (2008) 4867-4874.

7. WEI, R.; BOOKER, T.; RINCON, C.; ARPS,J., Surf. Coat. Technol. 186 (2004) 305-313.

8. CHEN, A.; SCHEUER, J.T.; RITTER, C.; ALEXANDER, R.B.; CONRAD, J.R., J. Appl. Phys. 70 (1991) 6757-6760.

9. DUCHEROW, M.; FLEISCHER, A.; MÄNDL, S., Plasma Proc. Polymers 4 (2007) S602-S606.

10. VIEIRA, P. R. S. M. R., Titânio e Suas Ligas.

11. ANDRADE, A.; MORCELli, A.; LOBO, R., Deformation and Fracture of an Alpha/Beta Titanium Alloy.
12. GURRAPPA, I. Characterization of titanium alloy Ti-6Al-4V for chemical, marine and industrial applications. Mater. Charact., v. 51, p. 131- 139, 2003.

13. CONRAD, J.R.; RADTKE, J.L.; DODD, R.A.; WORZALA, F.J., J. Appl. Phys. 62 (1987) 4591-4596.

14. TENDYS, J.; DONNELLY, I.J.; KENNY, M.J.; POLLOCK, J.T.A., Appl. Phys. Lett. 53 (1988) 2143-2145.

15. MANOVA, D.; GERLACH, J.W.; NEUMANN, H.; ASSMANN, W.; MÄNDL, S., Nucl. Instrum. Meth. B 242 (2006) 282-284

16. MAROT, L.; DROUET, M.; BERNEAU, F.; STRABONI, A., Surf. Coat. Technol. 156 (2002) 155-158.

17. MELLO, C.B.; UEDA, M.; SILVA, M.M.; REUTHER, H.; PICHON, L.; LEPIENSKI, C.M., Wear 267 (2009) 867-873.

18. SAVONOV, G.S.; UEDA, M.; OLIVEIRA, R.M.; OTANI, C., Surf. Coat. Technol. 206 (7) (2011) 2017-2020.

19. UEDA, M.; OLIVEIRA, R.M.; ROSSI, J.O.; MELLO, C.B.; RANGEL, R.C.C.; VIEIRA, M.S., Surf. Coat. Technol. 229 (2013) 97-104.

20. OliVEIRA, R.M.; MELLO, C.B.; SILVA, G.; GONÇALVES, J.A.N.; UEDA, M.; PICHON, L., Surf. Coat. Technol. 205 (2011) S111-S114

21. RAMOS, E. C. T.; SILVA, G.; RAMOS, A. S.; NUNES, C. A.; BAPTISTA. C. A. R. P., Mater. Sci. Eng. A 363 (2003) 297-306.

22. STACHOWIAK, G. W.; BATCHELOR A.W., Engineering Tribology, 3rd ed., Elsevier Butterworth Heinemann, 2005, p.419.

23. SHTANSKY, D.V.; SHEVEIKO, A.N.; PETRZHIK, M.I.; KIRYUKHANTSEV-KORNEEV, F.V.; LEVASHOV, E.A.; LEYLAND, A.; YEROKHIN, A.L.; MATTHEWS, A., Surf. Coat. Technol. 200 (2005) 208-212.

24. SHTANSKY, D.V.; LEVASHOV, E.A.; SHEVEIKO, A.N.; MOORE, J.J., J. Mater. Synthesis Proc. 6 (1) (1998) 61-72.

25. TAMURA, M.; KUBO, H., Surf. Coat. Technol. 54/55 (1) (1992) 255-260.

26. FERNANDES, B.N.; OLIVEIRA, R.M.; UEDA, M.; MARIANO, S.F.M.; RAMOS, A. S.; VIEIRA, M.S.; MELO, F.C.L.; OLIVEIRA,G. Surf. Coat. Technol. 228 (2013) 195-200.

27. FERNANDES, B.B., Ph.D. Thesis. Technological Institute of Aeronautics, São José dos Campos, Brazil, 2010.

28. TARRÉS, E.; RAMÍREZ, G.; GAILLARD, Y.; JIMÉNEZ-PIQUÉ, E.; LLANES, L., Int. J. Refract. Met. Hard Mater. 27 (2009) 323-331.

29. CARVALHO, N.J.M.; DE HOSSON, J. TH., Acta Mater. 54 (2006) 1857-1862.

30. OSSA, E.A.; DESHPANDE, V.S.; CEBON, D., Acta Mater. 53 (2005) 3103-3113

31. XU, B.X.; YUE, Z.F.; WANG, J., Mech. Mater. 39 (2007) 1066 1080

32. CAIRNEY, J.M.; TSUKANO, R.; HOFFMAN, M.J.; YANG, M., Acta Mater. 52 (2004) 3229-3237.

33. BARSOUM, M.W.; MURUGAIAH, A.; KALIDINDI, S.R.; ZHEN, T.; GOGOTSI, Y., Carbon 42 (2004) 1435-1445.

34. ESKNER, M., Doctoral Thesis. Royal Institute of Technology, Sweden, 2004

35. OLIVEIRA, R.M.; GONÇALVES, J.A.N.; UEDA, M.; ROSSI, J.O.; RIZZO, P.N., Surf. Coat. Technol. 204 (2010) 3009-3012. 
36. MÄNDL. S.,Surf. Coat. Technol. 201 (2007) 6833-6838.

37. VEPREK, S.; ARGON, A.S.; ZHANG, R.F., Phil. Mag. Lett. 87 (2007) 955-966.

38. MOHSENI, H.; NANDWANA, P.; TSOI, A.; BANERJEE, R.; SCHARF, T.W., Acta Mater. 83 (2015) 61-74.

39. RODRIGUES, S. H., Análise de Dados de Nanoindentação de Liga de Alumínio 7075 Tratado por 3IP.
40. MURAGAIAH, A.; BARSOUM, M.W.; KALINDINI, S.R.; ZHEN, T. J. Mater. Res. 19 (7) (2004) 2194-2203.

41. MOHSENI, H.; NANDWANA, P.; TSOI, A.; BANERJEE, R.; SCHARF, T.W., Acta Mater. 83 (2015) 61-74.

42. SCHWARZER, N.; RICHTER, F.; HECHT, G., Surf. Coat. Technol. 114 (1999) 292-303.

43. KARSCH, T.; BOMAS, H.; ZOCH, H.-W.; MÄNDL, S., Int. J. Fatigue 60 (2014) 74-89. 